\title{
Bargaining Power of Suppliers and Buyers, and Accounting Conservatism-Evidence from Chinese Manufacturing Listed Companies
}

\author{
Ziqiang Zhao1* ${ }^{*}$, Dixi Wu' ${ }^{2}$, Sha Sha ${ }^{3}$ \\ ${ }^{1}$ Department of Accounting and Finance, Nanjing Normal University, Nanjing, China \\ ${ }^{2}$ College of Economics and Management, Nanjing University of Science and Technology, Nanjing, China \\ ${ }^{3}$ College of Computer Science and Technology, Nanjing Normal University, Nanjing, China \\ Email: 4 45036@njnu.edu.cn
}

Received 28 November 2014; accepted 1 March 2015; published 4 March 2015

Copyright (C) 2015 by authors and Scientific Research Publishing Inc.

This work is licensed under the Creative Commons Attribution International License (CC BY). http://creativecommons.org/licenses/by/4.0/

\section{(c) (i) Open Access}

\begin{abstract}
Using the panel data of Chinese manufacturing listed companies from 2003 to 2012, this paper examines the effects of suppliers' and franchisers' (buyers') bargaining power on accounting conservatism. The empirical research proves that there is an inverted $U$-shape relationship between suppliers' bargaining power and conditional conservatism, with lower left wing and higher right wing. The relationship between franchisers' (buyers') bargaining power and conditional conservatism is not significant. On the contrary, there is a $U$-shape relationship between suppliers', franchisers' (buyers') bargaining power and unconditional conservatism. The relationship between suppliers' bargaining power and unconditional conservatism has higher left wing and lower right wing. Our research results explain how strong suppliers and franchisers (buyers) affect companies' accounting practices in the Chinese context. In the meantime, our results provide support to the contracting explanation for accounting conservatism.
\end{abstract}

\section{Keywords}

Financial Disclosures, Accounting Conservatism, Concentration Degree, Suppliers, Franchisers

\footnotetext{
${ }^{*}$ Corresponding author.
}

How to cite this paper: Zhao, Z. Q., Wu, D. X., \& Sha, S. (2015). Bargaining Power of Suppliers and Buyers, and Accounting Conservatism-Evidence from Chinese Manufacturing Listed Companies. Journal of Financial Risk Management, 4, 11-21. 


\section{Introduction}

\subsection{Background}

A firm's corporate suppliers and franchisers (buyers) use its accounting performance to measure its underlying economic performance. Suppliers and franchisers (buyers) will consider the firm's accounting performance when evaluating if it can meet its short-term trading obligations. Likewise, long-term suppliers and franchisers (buyers) study the firm's accounting performance to assess its long-term financial viability and the risk of making relationship-specific investments. For instance, a supplier involved in a long-term transaction with a firm might acquire specialized assets to manufacture specific products for the firm, while a customer involved in a long-term transaction may tailor its production technology to process products purchased from the firm. If the firm were to go bankrupt, the supplier and customer could face large switching costs. Suppliers and franchisers (buyers) involved in long-term transactions with a firm will also consider its accounting performance when evaluating the possibility that the firm might experience financial distress and no longer perform their implicit contracts. A supplier could be concerned with whether the firm can continue providing it with revenue from the products it sells to the firm, while a customer might be worried about whether the firm can provide it with continued high quality spare parts and service for the products it buys from the firm (Titman and Wessels, 1988; Bowen et al., 1995; Banerjee et al., 2008).

The importance of a firm's economic performance to its suppliers and franchisers (buyers) leads to a demand from these stakeholders for the firm to report more conservatively. Our study researches the relationship between suppliers', franchisers' (buyers') bargaining power and accounting conservatism of China's manufacturing listed companies. An early definition of "accounting conservatism" is given by Bliss (1924), who explains it as "anticipate no profit, but anticipate all losses". This means that profits are not acknowledged before there is a verifiable legal claim that these profits will actually be generated. However, this does not mean that absolutely no profit is being recognized before the revenues are actually received. The recognition depends on the verifiability. Another definition given by Basu (1997) is "the accountant's tendency to require a higher degree of verification to recognize good news as gains than to recognize bad news as losses". This implies that the greater the verification needed to recognize profits, the greater the conservatism will be. This conceptual background is used quite often in literature reviews. The last definition I would like to note is the definition given by Watts (2003). He states that "conservatism is defined as the differential verifiability required for recognition of profits versus losses". This definition tallies with the other two stated above. I therefore conclude that accounting conservatism is about an asymmetry between the verification of positive and negative income streams. Profits are being reported far more prudent while losses are being overestimated.

\subsection{Purpose and Significance}

Our findings provide support to the contracting explanation for accounting conservatism that the demand for conservatism in part occurs because it allows firms to contract more efficient contracts with related parties (Watts, 2003).

Our study broadly contributes to the literature that examines how product market competition influences accounting policy. Although the extent to which a firm competes for economic profits with suppliers and franchisers (buyers) is an important determinant of its survival (Porter, 1980; Perry, 1989), prior research on the impact of product market competition on accounting policy focuses on the competitiveness of a firm's own industry (Bamber and Cheon, 1998; Harris, 1998; Verrecchia and Weber, 2006; Ali et al., 2009). Our findings suggest that the bargaining power of a firm's suppliers and franchisers (buyers) is also an important determinant of its accounting practices.

\section{Literature Review}

\subsection{Summary of Foreign Studies}

Transaction cost theory posits that, in many cases, there is a high likelihood that the parties involved in longterm contracts engage in post-contractual opportunistic behavior. Ball (1989) proposes that accounting can act the part of providing information that assists firms in establishing their quasi-pricing system used for contracting purposes. In this functional completion role of accounting, conservatism is desirable because it helps complete ex ante incomplete contracts by providing more reliable quasi-prices to prevent opportunistic behavior. 
Watts (2003) predicts that because creditors usually have bargaining advantages over firms and thus determine borrowing terms, one reason firms adopt more conservative accounting policies is that accounting conservatism helps to limit creditors' downside risk, which in turn enables firms to obtain lower interest rates on their loans. Above research on accounting conservatism is mainly concerned with stakeholders of direct interests, such as shareholders, creditors, managers, and so on.

On this basis, some scholars begin to pay attention to the impacts stakeholders of indirect interests have on accounting conservatism. Basu (2001) find that firms audited by Big Eight auditors have greater conditional conservatism, consistent with Big Eight auditors having bargaining advantages compared to non-Big Eight auditors and consequently being able to impose conservatism. Farber (2012) suggests that strong labor unions restrict management from substituting high risk investments for low risk investments, which can reduce the demand for accounting conservatism from creditors. Therefore, stronger unions are associated with lower level of conservatism.

At present, the research on accounting conservatism from the perspective of suppliers-franchisers (buyers) relationship is rare. We argue that the importance of a firm's economic performance for its suppliers and customers leads to a demand from these stakeholders for the firm to report more conservatively. This argument follows the contracting rationale for accounting conservatism (Watts, 2003) that conservatism helps address moral hazard caused by parties to the firm having asymmetric information and asymmetric payoffs. As such, our argument is in part analogous to the proposition that the demand for accounting conservatism is partly due to it facilitating contracting between the firm and creditors. Similar to contracting between firms and creditors, contracting between firms and their suppliers and franchisers is made difficult due to agency problems resulting from information asymmetry. Further, like creditors, suppliers and franchisers have asymmetric payoffs with respect to a firm's performance. Telser (1980), Klein and Leffler (1981) and Bull (1987) propose that when deciding whether to transact with a particular firm or what terms to offer the firm, suppliers and franchisers (buyers) place significant importance on the firm's reputation for performing the stakeholders' implicit contracts. Bowen et al. (1995) and Burgstahler and Dichev (1997) argue that firms with higher reported earnings are perceived by their suppliers and franchisers (buyers) as being more likely to remain financially viable in the long-term and to perform the long-term implicit contracts. Hui et al. (2012) argues that conservatism is one viable and mutually beneficial mechanism that suppliers and franchisers (buyers) could use to protect themselves and can reduce the costs of companies effectively when contracting with a firm.

\subsection{Summary of Domestic Studies}

Zhang Jiehui (2008) finds that the principle of accounting conservatism can solve the problem of information asymmetry between companies and outside investors. Conservatism can help investors avoid possible risk effectively. Xu Quanhua (2011) argues that information asymmetry is the basic problem, which needs to be solved in the financial accounting. In the case of asymmetric information, conservative financial reporting and corporate voluntary disclosure of information will form a trade-off between each other. Accounting conservatism can improve information transparency and give play to the role of regulation.

Jiang Yan (2012) finds that with the improvement of asset specificity level, the degree of accounting conservatism will also increase. On the one hand, as a form of private information communication, accounting conservatism is a commitment mechanism, which is advantageous to the signing and executing contracts. On the other hand, as a kind of supervision mechanism, accounting conservatism can reduce the possibility of contract default. In addition, through the intermediary effect analysis method, the study found that the asset specificity affects accounting conservatism through the capital structure.

In general, foreign scholars have conducted the research in view of the relevance between stakeholders and accounting conservatism, but few have studied the impact suppliers and franchisers (buyers) have on accounting conservatism. At present, we have not found domestic scholars who studied suppliers, franchisers (buyers) and accounting conservatism. The work of this paper makes up for the domestic research blank, and can provide international related research evidence from China.

\section{Research Hypothesis}

The contracting rationale for accounting conservatism (Watts, 2003) argues that conservatism helps address moral hazard caused by parties to the firm having asymmetric information and asymmetric payoffs. The demand 
for accounting conservatism is partly due to it facilitating contracting between the firm and creditors. Further, like creditors, suppliers and franchisers (buyers) have asymmetric payoffs with respect to a firm's performance. For instance, if the firm's future performance is above expected levels, franchisers (buyers) would gain little from this as long as at expected performance levels the firm would have fulfilled its contractual obligations to these stakeholders. Also, although a firm's suppliers could benefit if it performs unusually well and this leads to it buying more from suppliers, the expected upside to suppliers due to the firm's strong performance could still be limited. In contrast, if a firm were to experience financial difficulty or even go bankrupt, suppliers or franchisers (buyers) involved in short-term discrete transactions, long-term transactions, or relational transactions with the firm could incur large costs if it reneged on its contractual obligations to them or did not perform these stakeholders' implicit contracts. Hui et al. (2012) argues that conservatism is one viable mechanism that suppliers and franchisers (buyers) could use to protect themselves when contracting with a firm. Thus, we put forward the first hypothesis:

Hypothesis 1: The stronger bargaining power suppliers and franchisers (buyers) of our domestic company has, the higher the level of conditional conservatism of the company will be.

Bowen et al. (1995) predict that firms needing to fulfill greater implicit claims with suppliers and franchisers (buyers) are more likely to manage their earnings upwards by choosing aggressive accounting methods (i.e., less unconditional conservatism). Although conditional and unconditional conservatism looks similar, both of them can result in a decrease of the net assets of companies. The empirical study of Pope and Walker (2003), Pae (2004) and Roychowdhury and Watts (2007) shows that unconditional conservatism negatively relates conditional conservatism. Using the general models of two kinds of conservatism, Beaver and Ryan (2005) provides further explanation for the negative correlation between the two. Unconditional conservatism can reduce the proportion of assets, which are under the control of conditional conservatism. For example, increasing the ratio of intangible assets whose cost is included in expense directly, resulting in a decline in the stock return rate and increasing the asymmetry between the companies and investors, so conditional conservatism declines. Thus, we put forward the second hypothesis:

Hypothesis 2: The stronger bargaining power suppliers and franchisers (buyers) of our domestic company has, the lower the level of unconditional conservatism of the company will be.

Zhang Ming (2012) argues that, in the supply chain, suppliers or franchisers (buyers) obtain more private information, know more about the situation of companies, their demand for public information will drop. In the supply chain, there is a threshold between suppliers' and franchisers' (buyers') concentration. Before the threshold, the company can exert effective control to its suppliers or franchisers (buyers), and there is a strong relation of cooperation between them. With the increase of suppliers' and franchisers' (buyers') concentration, the close degree between the company and its suppliers or franchisers (buyers) gradually rises. Within limits, the company will provide them with more private information, thus the demand from suppliers or franchisers (buyers) for the public information such as audit will gradually decline. Therefore, it can be expected that before the threshold is reached, with the increase of suppliers' and franchisers' (buyers') concentration, the possibility of the company employs large auditors (for example: Big Four auditors) will decline. However, as the further increase of suppliers' and franchisers' (buyers') concentration, the relative strength between the company and its suppliers or franchisers (buyers) will change. When the concentration is higher than the threshold, suppliers' and franchisers' (buyers') bargaining power is stronger than the company, causing them to have absolute control of the company (Dowlatshahi, 1999), and through this control, they can force the company to provide more private information. This means that after reaching the threshold, with the increase of suppliers' and franchisers' (buyers') concentration, the possibility of the company employing large auditors (for example: Big Four auditors) will increase. It can be concluded from this that there is a $U$-shape relationship between suppliers', franchisers' (buyers') concentration and the possibility of the company employing large auditors. Empirical results show that when companies are subject to suppliers and franchisers (buyers), those with good government relations are more likely to take advantage of government support and others to obtain a better position competing with suppliers and franchisers (buyers), and through good certified public accountants and the high quality auditing, they can deliver their own high quality signals to potential partners. Liu Feng and Zhou Fuyuan (2007) find that from the perspective of conditions, strong evidence shows that Big Four auditors is less conservatism than no Big Four auditors. Thus, we put forward the third hypothesis:

Hypothesis 3: There is an inverted $U$-shape relationship between bargaining power of suppliers, franchisers (buyers) and conditional conservatism. 
Similar to the theory basis of hypothesis 2, the empirical study of Pope and Walker (2003), Pae (2004) and Roychowdhury and Watts (2007) show that unconditional conservatism negatively relates to conditional conservatism. Wang Lina and Bao Chunguo (2007) studied the interaction between unconditional and conditional conservatism. Results show that unconditional and conditional conservatism is not independent, but have the relationship of mutual connection and restriction. Thus, we put forward the forth hypothesis:

Hypothesis 4: There is a $U$-shape relationship between bargaining power of suppliers, franchisers (buyers) and unconditional conservatism.

\section{Samples and Data}

\subsection{Sample Selection}

Taking Shanghai manufacturing companies as the research object, the period from 2003 to 2012 as sample interval, this paper studies empirically on the influence bargaining power of suppliers and franchisers (buyers) have on accounting conservatism. In this paper, the data is derived from CSMAR database and annual reports of listed companies. Because the database does not contain relevant data about the share companies purchase from the five largest suppliers and the share companies sell to the five largest franchisers (buyers). In order to determine the sample, we have taken actions to collect data manually from the annual reports of Shanghai stock exchange listed company. The samples are screened according to the following standards: 1) Suppliers and franchisers(buyers) this paper examined belong to the indirect stakeholders, so we excludes biological pharmaceutical listed companies from the sample, referring to Itzkowitz (2013). Unlike companies based on orders and voidable contracts, biological pharmaceutical listed companies need a lot of upfront investment. Its relationship with franchisers (buyers) is often reflected in a certain proportion of equity franchisers (buyers) stakes, which is a relationship of direct stakeholders and does not accord with the research object; 2) Eliminate cross listings (issue $B$ shares and $H$ shares) at the same time; 3) Eliminate the sample observation value of ST and *ST and the delisting; 4) Eliminate the listed companies whose final net worth less than 0 (financial leverage is greater than 1); 5) Eliminate the listed companies whose data missing. From 486 manufacturing companies in the Shanghai market, in the end we obtain the panel data of 390 companies 10 years.

\subsection{Research Variables}

\subsubsection{Dependent Variables}

This paper uses C-SCORE model which is proposed by Khan and Watts (2009) to measure conditional conservatism of a company in one year. The indicator argues that four factors Watts (2003) maintains which influence accounting conservatism, namely contract, litigation, regulation and tax, change with the companies' investment opportunity set. Based on Basu model, $C$-SCORE model is designed as the firm-level index of accounting conservatism, which uses Size, $M / B$, Lev as the proxy variable of investment opportunity set. Its computation formula is as follows:

$$
\begin{gathered}
\frac{X_{i, t}}{P_{i, t-1}}=\alpha_{0}+\alpha_{1} * D R_{i, t}+\alpha_{2} * R_{i, t}+\alpha_{3} * R_{i, t} * D R_{i, t}+\xi_{i, t} \\
\alpha_{2}=G \text {-SCORE }=\beta_{0}+\beta_{1} * \operatorname{Size}_{i, t}+\beta_{2} * M / B_{i, t}+\beta_{3} * \operatorname{Lev}_{i, t} \\
\alpha_{3}=C-\mathrm{SCORE}=\chi_{0}+\chi_{1} * \operatorname{Size}_{i, t}+\chi_{2} * M / B_{i, t}+\chi_{3} * \operatorname{Lev}_{i, t} \\
R_{i, t}=\left[\prod_{j=1}^{n}\left(1+\mathrm{RET}_{i, t}\right)-1\right]-\left[\prod_{j=1}^{n}\left(1+\mathrm{MRET}_{m, t}\right)-1\right]
\end{gathered}
$$

The meaning of each variable is as follows:

$X_{i, t} / P_{i, t-1}$ : Earnings per share/initial share price of $i$ company in $t$ year;

$R_{i, t}$ : Stock annual excess return rate was adjusted by the market. Calculation methods are shown as (4-4). Included $\mathrm{RET}_{i, t}$ is monthly stock returns considering the cash dividend reinvestment. $\mathrm{MERT}_{m, t}$ is monthly market returns considering the cash dividend reinvestment.

$D R_{i, t}$ : Dummy. It equals to one if $\mathrm{RET}_{i, t}$ is negative, and zero otherwise. 
Substituting model (4-2) and (4-3) into model (4-1):

$$
\begin{aligned}
\frac{X_{i, t}}{P_{i, t-1}}= & \alpha_{0}+\alpha_{1} * D R_{i, t}+\left(\beta_{0}+\beta_{1} * \operatorname{Size}_{i, t}+\beta_{2} * M / B_{i, t}+\beta_{3} * \operatorname{Lev}_{i, t}\right) * R_{i, t} \\
& +\left(\chi_{0}+\chi_{1} * \operatorname{Size}_{i, t}+\chi_{2} * M / B_{i, t}+\chi_{3} * \operatorname{Lev}_{i, t}\right) * R_{i, t} * D R_{i, t}+\xi_{i, t}
\end{aligned}
$$

According to the model (4-5), using cross-section data regression, we got the coefficients of each year $\beta_{0}$, $\beta_{1}, \beta_{2}, \beta_{3}, \chi_{0}, \chi_{1}, \chi_{2}, \chi_{3}$, and then we substituted coefficients into model (4-2) and model (4-3) and calculated $G$-SCORE and $C$-SCORE.

$G$-SCORE is the timeliness variable which is on behalf of the timeliness accounting surplus reflect to the "good news". C-SCORE is increment of the correlation of accountancy surplus and stock price when "bad news" occurs relative to itself when "good news" occurs. The greater C-SCORE shows that accounting information confirming "bad news" relative to the "good news" is in a more timely manner, i.e. the higher the degree of accounting conservatism.

Besides, in this paper we use negative cumulative accrued model (NA) proposed by Givoly and Hayn (2000) to measure the unconditional conservatism. The two forms of conservatism, conditional conservatism and unconditional conservatism, are usually argued to have different economic functions. While conditional conservatism is mostly viewed as beneficial, unconditional conservatism appears in a more negative light. Conditional conservatism is said to enhance both the stewardship (contracting) and decision-usefulness (information) functions of financial reporting (Watts, 2003). Also, the asymmetrically timely recognition of losses versus gains has been shown to convey useful information (e.g. Basu, 1997). The benefits of unconditional conservatism are less obvious and distinct from those of conditional conservatism. Ball and Shivakumar (2005) consider unconditional conservatism to be inefficient or at best neutral in contracting. Unconditional conservatism is argued to preempt informative conditional conservatism and therefore to result in a lower quality of information (Penman and Zhang, 2002). Givoly and Hayn (2000) argue that, as there is a reverse relationship between accrual accounting and operating cash flow usually, thus we can use negative cumulative accrued items as proxy variable of accounting conservatism. Zhang Jinxin and Wang Yi (2013) also adopted this model in the study of unconditional conservatism and corporate financing constraints. The econometric model is as follows:

$$
\text { CONSV_NA }{ }_{i, t}=- \text { NOPAC }_{i, t} / \mathrm{TA}_{i, t-1}
$$

NOPAC $_{i, t}$ is non-operating accrued items for companies, if the value is negative continuously, then accounting conservatism exists. Computation formula: NOPAC $_{i, t}=$ Total accrued items - Business accrued items (Total accrued items $=$ Net profit + depreciation - Net cash flows from operating activities; Business accrued items = Changes in accounts receivable + Inventory changes the forehead + Change the account receivable amount in advance - Changes in accounts payable amount - Changes in tax payable amount); $\mathrm{TA}_{i, t-1}$ is the final total assets of $i$ company in $t-1$ year.

\subsubsection{Independent Variable}

In this paper, with reference to Tang Yuejun (2009), we use the suppliers' and franchisers’ (buyers') concentration as suppliers' and franchisers' (buyers') measure of bargaining power. We use Proportion of the share companies purchase from the five largest suppliers accounts total share in the sample enterprise annual report disclosed in the notes to measure of suppliers' bargaining power. Similarly, We use Proportion of the share companies sell to the five largest franchisers (buyers) accounts total share to measure of franchisers' (buyers') bargaining power. It conforms to the structural strength matrix measuring the relationship between supply and demand which is put forward by Dowlatshahi (1999) that in a one-to-many relationship, the one with smaller number will be in a dominant position. Therefore, the higher the suppliers' and franchisers' (buyers') concentration, the greater suppliers' and franchisers' (buyers’) bargaining power.

\subsubsection{Control Variables}

As we have not found domestic scholars who studied suppliers, franchisers (buyers) and accounting conservatism, we ultimately selected the following indicators as control variables in the regression model referring to Hui et al. (2012): 
1) Size: Natural log of the final total assets. The studies of Giner and Rees (2001), La Fond and Watts (2008), La Fond and Roychowdhury (2008) show that large firms report less conservatively.

2) MTB: The final price-to-book ratio. Watts (2003) argues that firms with a high market-to-book ratio are expected to have larger growth opportunities and therefore are likely to face higher contracting costs. According to the effective contract theory of accounting conservatism, this implies a positive association between the firm-specific timeliness measure of conservatism and the market-to-book ratio.

3) Leverage: Asset-liability ratio at the end of period. Ahmed (2002) points out that the higher financial leverage that the companies have can aggravate the conflict of interest between shareholders and creditors, so creditors' demand for accounting conservatism will be more intense.

4) Z-SCORE: Default risk is calculated following $Z$ model. Controlling for a firm's default risk is important because shareholder-bondholder conflicts of interest and the demand from bondholders for a firm to report conservatively should be greater if the likelihood of the firm defaulting on its debt is larger. Also, suppliers' and franchisers (buyers)' preferences for a firm to report conservatively should be greater if the firm faces a larger default risk.

5) Cashflow: The ratio of operating cash flow to total assets. For firms that have lower cash flows, further reductions in reported cash flows due to conservative accounting practices could be costly and thus make firms with lower cash flows less likely to follow conservative accounting policies.

6) SelfHHI: In this paper, based on the classification of manufacturing of the Shanghai stock exchange, the sample were classified as 9 industries. We further control for the firm's own industry concentration ratio, as captured by the Herfindahl-Hirschman index (SelfHHI), because firms in more concentrated industries could be more likely to hide bad news which would lead to lower accounting conservatism (Dhaliwal et al., 2009).

\section{Study Design}

We use multiple linear regression models to test the relationship between suppliers', franchisers' (buyers') bargaining power and accounting conservatism.

$$
\begin{aligned}
\text { CONSV }_{i, t}= & b_{0}+b_{1} \text { Supp }_{i, t}+b_{2} \text { Buyer }_{i, t}+b_{3} \text { Size }_{i, t}+b_{4} \text { MTB }_{i, t}+b_{5} \text { Leverage }_{i, t}+b_{6} Z \text { Z-SCORE } \\
& +b_{8} \text { SelfHHI }_{i, t}+\varepsilon_{i, t} .
\end{aligned}
$$

The above regression can be used to test Hypothesis 1 and Hypothesis 2, whether there is a linear relationship between suppliers', franchisers' (buyers') bargaining power and accounting conservatism. To test the hypothesis 3 and hypothesis 4 , we added squared terms of suppliers' and franchisers' (buyers') degree of concentration in the regression equation. Building on Equation (5-1), we structure Equation (5-2) for further:

$$
\begin{aligned}
\text { CONSV }_{i, t}= & b_{0}+b_{1} \text { Supp }_{i, t}+b_{2} \text { Buyer }_{i, t}+b_{3} \text { Supp }_{i, t}^{2}+b_{4} \text { Buyer }_{i, t}^{2}+b_{5} \text { Size }_{i, t}+b_{6} \text { MTB }_{i, t}+b_{7} \text { Leverage }_{i, t} \\
& +b_{8} \text { Z-SCORE }_{i, t}+b_{9} \text { Cashflow }_{i, t}+b_{10} \text { SelfHHI }_{i, t}+\varepsilon_{i, t} .
\end{aligned}
$$

\section{Empirical Results and Analysis}

\subsection{Pearson Correlation Coefficient}

Before regression analysis, we should examine the Pearson correlation coefficients of main variables in models first. Pearson correlation coefficients of key variables in both conditional and unconditional conservatism regression models are lower than 0.4 , which indicates a weak correlation between variables and small multicollinearity. In order to reduce multicollinearity problems between experimental variables and quadratic terms, we do central treatment to Supp and Buyer before building the squared terms (Chen Xiaoping et al., 2008; Cohen et al., 2013).

\subsection{C-SCORE Model}

In this paper, we use Khan and Watts' (2009) C-SCORE model to measure conditional conservatism, descriptive statistics of variables in the model are omitted here. It reports the mean, standard deviation and other statistics of the variables in the model (4-5). During the sample period, the mean value of $X_{i, t} / P_{i, t-1}$ is 0.017075 , and the mean value of $R_{i, t}$ is 0.073393 . In each year, there are some fluctuations between the variables, in which MTB fluctuates greatly. The specific calculation process has been explained in previous analysis. 
We calculate the value of conditional conservatism of the sample companies in each year, and conduct descriptive statistics upon it. It was found that in the whole sample, the mean value of conditional conservatism is 0.051447 and the standard deviation value of it is 0.336971 . Grouped according to the annual statistics, the mean value of listed companies' conditional conservatism is highest in 2005.

\subsection{Conditional Conservatism and Bargaining Power of Suppliers and Franchisers}

Because the sample is panel data including cross-section and time series, after Hausman test, the $P$ values of regression model (5-1), (5-2) are 0.0000, we decide to use the fixed effects model. The Pearson correlation coefficients of Size and C-SCORE, Lev and C-SCORE, Lev and Z-SCORE are relatively larger. Therefore, in the regression process of conditional conservatism and bargaining power of suppliers and franchisers (buyers), we removed the control variables Size and Leverage to reduce the multicollinearity impact on the results.

Table 1 shows the analysis results of the conditional conservatism regression model, at the $5 \%$ significance level, the results of the regression model (5-1) partially support the hypothesis 1 . The greater the proportion of the share companies purchase from the five largest suppliers accounts total share, namely, the greater the concentration of suppliers, the stronger bargaining power relative to companies, the level of companies' conditional conservatism is higher. Unlike suppliers, the positive relationship between franchisers' (buyers') bargaining power and conditional conservatism is not significant. After adding the squared term, the results of the regression model (5-2) partially support the hypothesis 3 . There is an inverted $U$-shape relationship between the proportion of the share companies purchase from the five largest suppliers accounts total share and conditional conservatism. Accordingly, it can be considered that there is an inverted $U$-shape relationship between suppliers' bargaining power and conditional conservatism. However, the inverted $U$-shape relationship between franchisers' (buyers') bargaining power and conditional conservatism is not significant. Considering the regression results of model (5-1) and models (5-2), we find that there is an inverted $U$-shape relationship between suppliers' bargaining power and conditional conservatism, with lower left wing and higher right wing. Relationship between the two is shown in Figure 1.

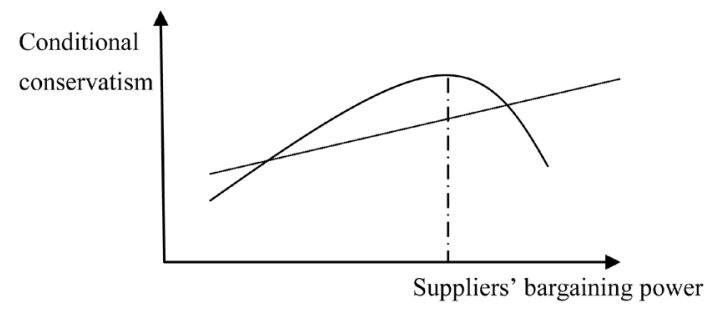

Figure 1. Suppliers’ bargaining power and conditional conservatism.

Table 1. Analysis results of the conditional conservatism regression model.

\begin{tabular}{ccccc}
\hline Variable & & Pred. Sign & Model $(5-1)$ & Model $(5-2)$ \\
Supp & & + & $0.061295(2.468)^{* *}$ & $0.218879(2.857)^{* * *}$ \\
Supp ${ }^{2}$ & - & & $-0.175783(-2.182)^{* *}$ \\
Buyer & & + & $0.022839(0.772)$ & $0.057433(0.688)$ \\
Buyer & & - & & $-0.043947(-0.444)$ \\
MTB & & + & $-0.00354(-5.259)^{* * *}$ & $-0.003475(-5.160)^{* * *}$ \\
Z-SCORE & & + & $-0.00171(-2.925)^{* * *}$ & $-0.001664(-2.833)^{* * *}$ \\
Cashflow & & + & $-0.099239(0.622)$ & $0.025795(0.557)$ \\
SelfHHI & & + & $0.028796(-1.055)$ & $-0.095906(-1.02)$ \\
& $R^{2}$ & & 0.318 & 0.320 \\
& Adjusted $R^{2}$ & & 0.185 & 0.186 \\
& $F-S t a t i s t i c$ & & 2.390 & 2.395 \\
& $N$ & & 2397 & 2397 \\
\hline
\end{tabular}

Note: The values in parentheses are $t$ values; ${ }^{*},{ }^{* *}$ and ${ }^{* * *}$ indicate two-tailed significance at $1 \%, 5 \%$, and $10 \%$ significance levels. 


\subsection{Cumulative Accrual Model (NA)}

In this paper, we use Givoly \& Hayn's (2000) cumulative accrual model to measure unconditional conservatism. From descriptive statistics of the variable CONSV_NA (Table 2), we can find that the values of unconditional conservatism annual mean measured by NA model is negative. This suggests that accruals of more than half of the companies may be positive, that the unconditional conservatism level of Chinese listed companies is not high.

\subsection{Unconditional Conservatism and Bargaining Power of Suppliers and Franchisers}

Table 3 shows the analysis results of the unconditional conservatism regression model, at the $1 \%$ significance level, the results of the regression model (5-1) partially support the hypothesis 2 . The greater the proportion of the share companies purchase from the five largest suppliers accounts total share, namely, the greater the concentration of suppliers, the stronger bargaining power relative to companies, the level of companies' unconditional conservatism is lower. However, the negative relationship between franchisers' (buyers') bargaining power and unconditional conservatism is not significant. After adding the squared term, the results of the regression model (5-2) partially support the hypothesis 4 . There is a $U$-shape relationship between the proportion of the share companies purchase from the five largest suppliers accounts total share and unconditional conservatism. Accordingly, It can be considered that there is a $U$-shape relationship between suppliers' bargaining power and unconditional conservatism. Similarly, there is a $U$-shape relationship between franchisers' (buyers') bargaining power and unconditional conservatism. Considering the regression results of model (5-1) and models (5-2), we find that the relationship between suppliers' bargaining power and unconditional conservatism has higher left wing and lower right wing. At the same time, there is a $U$-shape relationship between franchisers' (buyers') bargaining power and unconditional conservatism. We can roughly describe the figures of the relationship between suppliers', franchisers' (buyers') bargaining power and unconditional conservatism (Figure 2 and Figure $3)$.

\section{Conclusion}

Using the panel data of Chinese manufacturing listed companies from 2003 to 2012, this paper examines the effects of suppliers' and franchisers' (buyers') bargaining power on accounting conservatism. The empirical research proves that there is an inverted $U$-shape relationship between suppliers' bargaining power and conditional conservatism, with lower left wing and higher right wing in China. The relationship between franchisers' (buyers') bargaining power and conditional conservatism is not significant. On the contrary, there is a $U$-shape relationship between suppliers', franchisers' (buyers') bargaining power and unconditional conservatism. The relationship between suppliers' bargaining power and unconditional conservatism has higher left wing and lower right wing.

Table 2. Descriptive statistics of unconditional conservatism.

\begin{tabular}{clccccc}
\hline Period & Variable & Sample size & Mean & Standard deviation & Maximum & Minimum \\
\hline 2003 & CONSV_NA & 274 & -0.122484 & 0.161172 & 0.385939 & -0.82709 \\
2004 & CONSV_NA & 292 & -0.110096 & 0.165426 & 0.90091 & -0.886634 \\
2005 & CONSV_NA & 332 & -0.123446 & 0.133091 & 0.282159 & -0.567067 \\
2006 & CONSV_NA & 332 & -0.138461 & 0.201582 & 1.153386 & -1.7747 \\
2007 & CONSV_NA & 338 & -0.174332 & 0.286673 & 1.84181 & -3.079623 \\
2008 & CONSV_NA & 337 & -0.139716 & 0.152059 & 0.336131 & -0.853659 \\
2009 & CONSV_NA & 340 & -0.169862 & 0.177248 & 0.658085 & -0.933718 \\
2010 & CONSV_NA & 342 & -0.175931 & 0.182829 & 0.564052 & -1.241642 \\
2011 & CONSV_NA & 354 & -0.191725 & 0.24631 & 1.410438 & -3.098576 \\
2012 & CONSV_NA & 376 & -0.334513 & 2.082161 & 0.667382 & -36.01379 \\
$2003-2012$ & CONSV_NA & 3317 & -0.171914 & 0.726967 & 1.84181 & -36.01379 \\
\hline
\end{tabular}




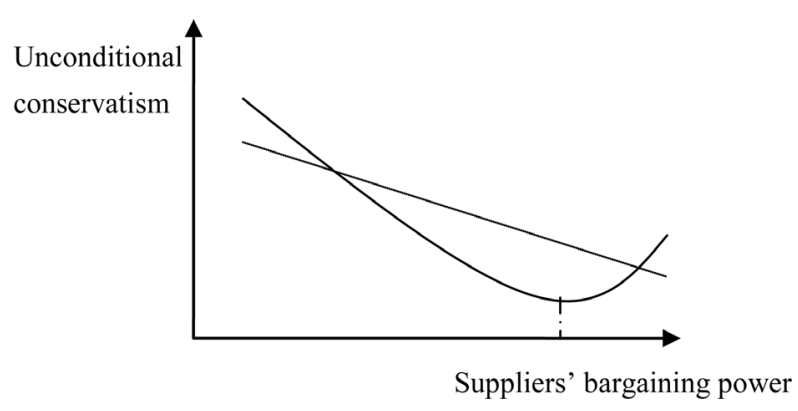

Figure 2. Suppliers’ bargaining power and unconditional conservatism.

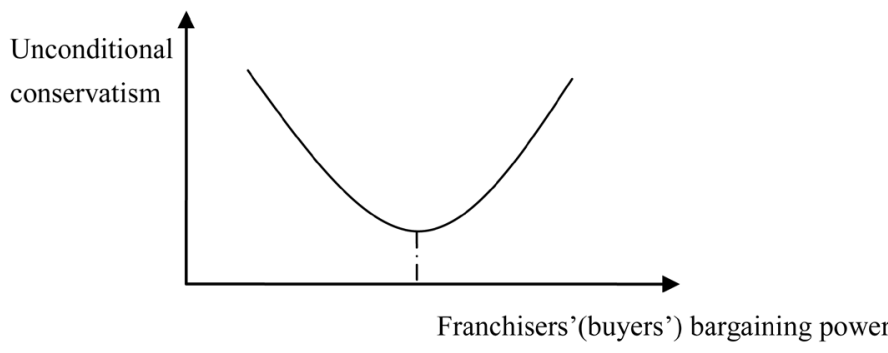

Figure 3. Franchisers' (buyers') bargaining power and unconditional conservatism.

Table 3. Analysis results of the unconditional conservatism regression model.

\begin{tabular}{|c|c|c|c|}
\hline Variable & Pred. Sign & Model (5-1) & Model (5-2) \\
\hline Supp & - & $-0.105331(-5.630)^{* * *}$ & $-0.297599(-4.224)^{* * *}$ \\
\hline Supp $^{2}$ & + & & $0.21948(2.917)^{* * *}$ \\
\hline Buyer & - & $-0.001520(-0.070)$ & $-0.161638(-2.347)^{* *}$ \\
\hline Buyer $^{2}$ & + & & $0.201407(2.481)^{* *}$ \\
\hline Size & + & $-0.046974(-13.142)^{* * *}$ & $-0.049433(-13.670)^{* * *}$ \\
\hline МТВ & + & $0.000122(0.118)$ & $0.000147(0.143)$ \\
\hline Leverage & + & $0.313886(12.881)^{* * *}$ & $0.313654(12.910)^{* * *}$ \\
\hline Z-SCORE & + & $0.001352(2.121)^{* *}$ & $0.000972(1.51)$ \\
\hline Cashflow & + & $0.190145(3.796)^{* * * *}$ & $0.193630(3.874)^{* * *}$ \\
\hline SelfHHI & + & $0.123698(2.700)^{* * *}$ & $0.129489(2.831)^{* * *}$ \\
\hline \multicolumn{2}{|c|}{$R^{2}$} & 0.131 & 0.139 \\
\hline \multicolumn{2}{|c|}{ Adjusted $R^{2}$} & 0.127 & 0.134 \\
\hline \multicolumn{2}{|c|}{ F-Statistic } & 37.452 & 31.761 \\
\hline \multicolumn{2}{|c|}{$N$} & 1997 & 1997 \\
\hline
\end{tabular}

Note: The values in parentheses are $t$ values; ${ }^{*},{ }^{* *}$ and ${ }^{* * *}$ indicate two-tailed significance at $1 \%, 5 \%$, and $10 \%$ significance levels.

\section{Acknowledgements}

The authors gratefully acknowledge the support given by the Social Science Fund of Jiangsu Province regarding the project "The research of the mechanism of supply chain risk contagion and the assessment of credit risk with the participation of financial institutes" whose grant number is 14GLB004. 


\section{References}

Ali, A., Klasa, S., \& Yeung, E. (2009). The Limitations of Industry Concentration Measures Constructed with Compustat Data: Implications for Finance Research. Review of Financial Studies, 22, 3839-3871. http://dx.doi.org/10.1093/rfs/hhn103

Banerjee, S., Dasgupta, S., \& Kim, Y. (2008). Buyer-Supplier Relationships and the Stakeholder Theory of Capital Structure. The Journal of Finance, 63, 2507-2552. http://dx.doi.org/10.1111/j.1540-6261.2008.01403.x

Basu, S. (2001). Discussion of "On the Asymmetric Recognition of Good and Bad News in France, Germany and the United Kindom”. Journal of Business Finance and Accounting, 28, 1333-1349. http://dx.doi.org/10.1111/1468-5957.00417

Beaver, W. H., \& Ryan, S. G. (2005). Conditional and Unconditional Conservatism: Concepts and Modeling. Review of Accounting Studies, 10, 269-309. http://dx.doi.org/10.1007/s11142-005-1532-6

Farber, D., Hsieh, H. Y., Jung, B. et al. (2012). The Impact of Non-Financial Stakeholders on Accounting Conservatism: The Case of Labor Unions. SSRN 2001940.

Hui, K. W., Klasa, S., \& Yeung, P. E. (2012). Corporate Suppliers and Franchisers (Buyers) and Accounting Conservatism. Journal of Accounting and Economics, 53, 115-135. http://dx.doi.org/10.1016/j.jacceco.2011.11.007

Liu, F., \& Zhou, F. Y. (2007). Does the Big Four Means High Quality of Auditing. Accounting Research, 3, 79-87.

Roychowdhury, S., \& Watts, R. L. (2007). Asymmetric Timeliness of Earnings, Market-to-Book and Conservatism in Financial Reporting. Journal of Accounting and Economics, 44, 2-31. http://dx.doi.org/10.1016/j.jacceco.2006.12.003

Tang, Y. J. (2009). Bargaining Power of Suppliers and Franchisers, and Corporate Performance-Evidence from Chinese Manufacturing Listing Companies in the Year 2005-2007. Chinese Industrial Economy, 10, 67-76.

Watts, R. L. (2003). Conservatism in Accounting Part I: Explanations and Implications. Accounting Horizons, 17, $207-221$. http://dx.doi.org/10.2308/acch.2003.17.3.207

Zhang, J. X., \& Wang, Y. (2013). Accounting Conservatism and Corporate Financing Constraints—Research Based on Two Types of Perspectives of Accounting Conservatism. Accounting Research, 9, 44-50. 